\title{
Simulasi ETAP untuk Evaluasi Proteksi Gangguan Tegangan Lebih Generator Unit 3 PLTP Kamojang
}

\author{
RIFKI FIKRANDANI NUGRAHA, TEGUH ARFIANTO
}

\author{
Program Studi Teknik Elektro, Institut Teknologi Nasional Bandung, Indonesia \\ Email: rifki.fikrandani@gmail.com
}

Received 13 April 2021 | Revised 13 Mei 2021 | Accepted 24 Juni 2021

\begin{abstract}
ABSTRAK
Pada penelitian ini dilakukan evaluasi proteksi gangguan tegangan lebih pada generator Unit 3 PLTP Kamojang yang diproteksi oleh sebuah relay tegangan lebih menggunakan simulasi pada software ETAP. Simulasi dilakukan untuk melihat bagaimana cara kerja relay tegangan lebih dan bentuk tegangan lebih yang terjadi pada terminal generator. Skenario simulasi yang digunakan yaitu melakukan pelepasan beban 50,7 MW dan relay yang digunakan dalam simulasi berfungsi untuk menyalakan alarm saat terjadi tegangan lebih. Hasil simulasi memperlihatkan bahwa pada saat terjadi pelepasan beban, relay tegangan lebih menyalakan alarm 1,1 detik setelah membaca tegangan naik hingga $13 \mathrm{kV}$ atau sebesar $110 \%$ dari tegangan nominalnya, kemudian tegangan terminal generator naik hingga 13,2 kV hingga kembali ke kondisi steady state 5 detik setelah terjadi kenaikkan tegangan. Hasil simulasi tersebut menunjukkan bahwa relay tegangan lebih yang terpasang pada terminal generator Unit 3 bekerja sesuai dengan fungsinya yaitu untuk memberikan alarm ketika tegangan lebih terjadi.
\end{abstract}

Kata kunci: pelepasan beban, proteksi generator, relay proteksi, simulasi generator, tegangan lebih

\begin{abstract}
This study evaluates overvoltage fault protection on the generator Unit 3 PLTP Kamojang which is protected by an overvoltage relay using simulation on ETAP software. Simulations are carried out to see how the overvoltage relay works and the form of overvoltage that occurs at the generator terminals. The scenario used is by do a load shedding of 53,3MW, the relay used in this simulation has a function to turn on the alarm when overvoltage occurs. The results show that when a load shedding occurs, the overvoltage relay turns on the alarm 1,1 seconds after reading the voltage up to $13 \mathrm{kV}$ or $110 \%$ of the nominal voltage, then the generator terminal voltage rises to $13.2 \mathrm{kV}$ until it returns to steady state 5 seconds after the voltage increase. The simulation results indicate that the overvoltage relay installed at the generator terminal Unit 3 works according to its function, namely to provide a warning when an overvoltage occurs.
\end{abstract}

Keywords: generator protection, load shedding, overvoltage, protection relay, generator simulation 


\section{PENDAHULUAN}

Setiap komponen pada pembangkit listrik tentu harus terhindar dari gangguan yang dapat mengganggu proses pembangkitan listrik, karena dapat mengakibatkan terjadinya kerusakan alat dan mengancam keselamatan manusia (Shintawaty, 2014). Salah satu gangguan pada sistem tenaga listrik yaitu terjadinya tegangan berlebih atau overvoltage yang dapat disebabkan oleh beberapa hal seperti pelepasan beban mendadak dan kerusakan AVR (Grid, 2011) (Smith, 2011).

Menurut penelitian yang dilakukan oleh Widarsono (Widarsono, 2019) dan timnya, overvoltage merupakan gangguan dimana nilai tegangan naik lebih dari $110 \%$ dengan durasi lebih dari 1 menit. Akibat dari overvoltage yaitu dapat terjadinya degradasi peralatan tenaga listrik (berkurangnya masa penggunaan alat) dan kerusakan belitan rotor pada generator (Torres, 2008).

Proteksi untuk overvoltage pada sistem pembangkit tenaga listrik yaitu dengan menggunakan relay tegangan lebih (Overvoltage Relay) (Hussen, 2019). Secara sederhana prinsip kerja overvoltage relay yaitu mendeteksi tegangan dari potential transformer (PT) pada titik yang akan diproteksi kemudian dibandingan dengan tegangan setting pada relay sehingga apabila tegangan PT melebihi tegangan setting, maka relay akan bekerja untuk mengaktifkan PMT (Pemutus) atau menyalakan alarm (Grabovickic, 2012) (Hidayat, 2018).

Salah satu cara untuk mengetahui bagaimana relay tegangan lebih bekerja yaitu dengan cara simulasi menggunakan perangkat lunak penganalisis sitem tenaga listrik seperti ETAP. Metode untuk mensimulasikan relay proteksi menggunakan ETAP yaitu dengan memasukkan data-data sistem dan relay proteksi lalu mensimulasikan skenario gangguan dan menghitungnya, setelah itu dilakukan perhitungan setting relay lalu mensimulasikan kerja relay tersebut (Saputro, 2016).

Skenario simulasi yang dapat dilakukan untuk menciptakan gangguan tegangan lebih yaitu dengan melakukan pelepasan beban. Penelitian yang dilakukan oleh Jozi (Jozi, 2020) dan timnya menunjukkan bahwa pada saat simulasi menggunakan ETAP, pelepasan beban generator sebesar $15 \%$ dari total beban, tegangan pada bus generator naik sebesar $12 \%$ namun kembali turun dan stabil di kisaran $101 \%$ dari tegangan nominal, kemudian frekuensi mengalami penurunan terendah sebesar $94 \%$ pada detik ke 5 setelah dilakukan pelepasan beban dan kembali stabil setelah 24 detik.

Berdasarkan permasalahan diatas, akan dilakukan penelitian untuk mengevaluasi sistem proteksi tegangan lebih yang terpasang pada generator Unit 3 PLTP Kamojang, dengan perhitungan dan simulasi menggunakan software ETAP dengan skenario pelepasan beban generator. Kemudian akan didapatkan karakteristik tegangan lebih pada terminal generator dan waktu kerja relay tegangan lebih yang terpasang pada Generator Unit 3 PLTP Kamojang pada saat terjadi gangguan, sehingga akan diketahui apakah proteksi tegangan lebih yang terpasang pada generator Unit 3 PLTP Kamojang sudah sesuai dengan standar atau tidak. 


\section{METODE PENELITIAN}

\subsection{Diagram Alir Penelitian}

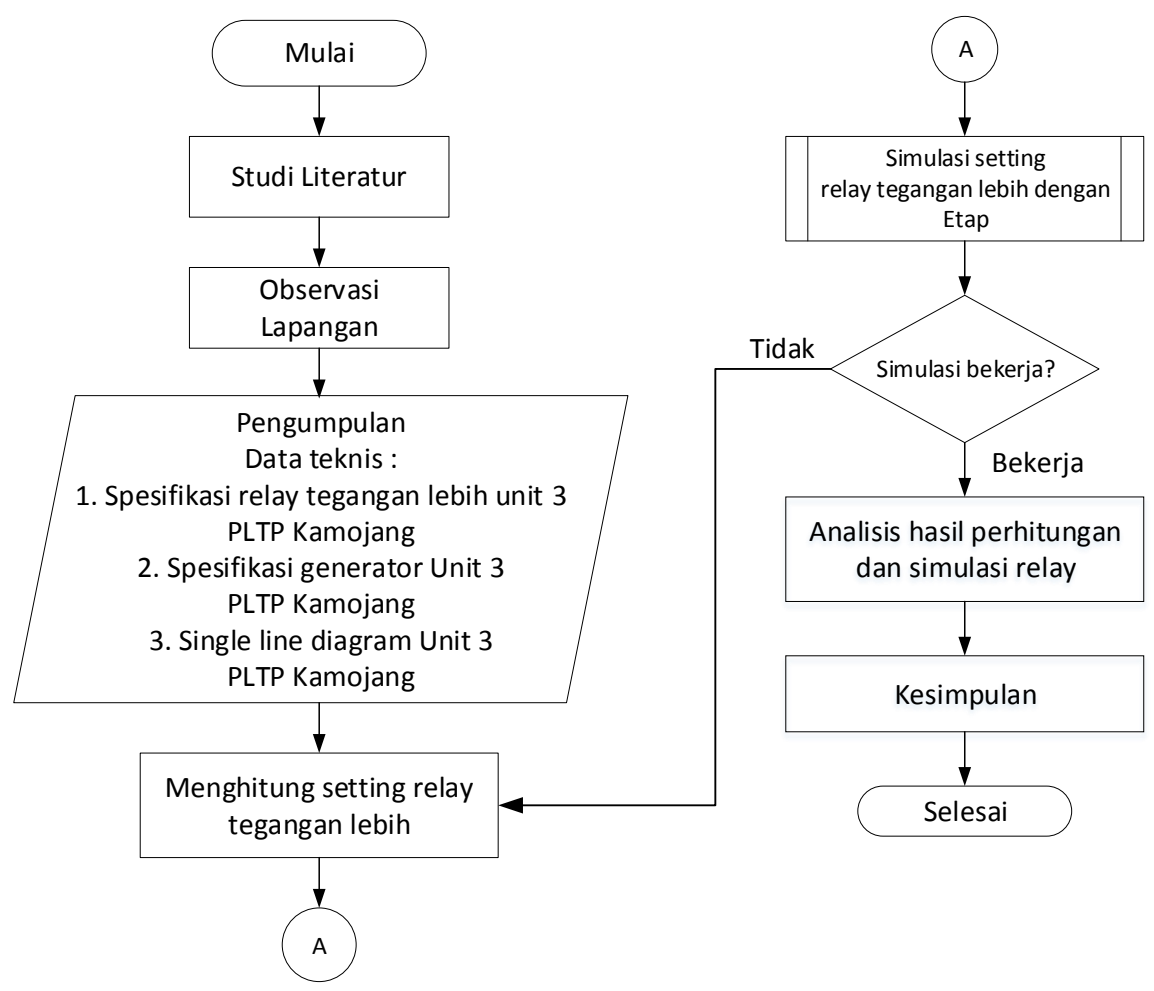

\section{Gambar 1. Diagram Alir Penelitian}

Berdasarkan diagram alir pada Gambar 1, dapat diketahui urutan proses penelitian ini, dimulai dengan dilakukan studi literatur, observasi lapangan, pengumpulan data, simulasi dan analisis data mengenai kondisi relay tegangan lebih yang digunakan di generator Unit 3 PLTP Kamojang.

\subsection{Perhitungan Setting Relay Tegangan Lebih}

Setelah didapatkan data teknis yang diperoleh dari studi literatur dan observasi lapangan, kemudian dilakukan perhitungan untuk mendapatkan nilai pengaturan atau setting yang dipakai oleh relay tegangan lebih yang terpasang pada terminal generator Unit 3 PLTP Kamojang. Terdapat dua parameter yang harus ditentukan untuk melakukan setting relay tegangan lebih yaitu nominal tegangan keluaran generator dan tegangan sekunder potential transformer (PT) yang terpasang pada terminal generator.

\subsubsection{Pengukuran Tegangan Terminal Generator}

Pengukuran tegangan terminal generator yaitu menggunakan Potential Transformers (PT). Dari hasil pengukuran tersebut akan didapatkan tegangan keluaran trafo yang selanjutnya akan menjadi input dari sistem proteksi tegangan lebih generator yaitu relay tegangan lebih. Data yang digunakan yaitu pengukuran beban mingguan generator Unit 3 PLTP Kamojang selama satu bulan. Gambar 2 menunjukkan diagram pemasangan PT. 


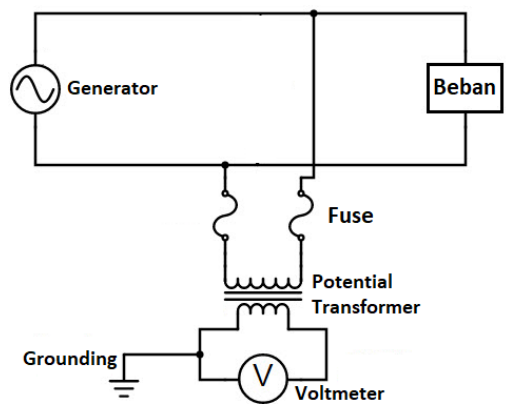

Gambar 2. Pemasangan PT (EIProCus Technologies Pvt Ltd, 2020)

\subsubsection{Perhitungan Tegangan Terminal Generator}

Setelah dilakukan pengukuran tegangan terminal generator kemudian dilakukan perhitungan untuk memastikan kebenaran hasil perhitungan. Untuk menghitung tegangan terminal generator dari data beban mingguan selama satu bulan dapat diketahui dengan menggunakan Persamaan (1) (Sudjoko, 2018).

$$
V_{T}=\frac{P_{3 \emptyset}}{\sqrt{3} \cdot I \cdot \cos \theta}
$$

Keterangan:

$\mathrm{I} \quad=$ Arus generator

$\mathrm{P}_{3 \varnothing} \quad$ = Daya generator 3 fasa

$\mathrm{V}_{\mathrm{T}} \quad=$ Tegangan terminal generator

$\cos \theta=$ Faktor daya

\subsubsection{Perhitungan Tegangan pada Sisi Sekunder Potential Transformer (PT)}

Salah satu fungsi Potential Transformer yaitu untuk mengkonversi tegangan menengah menjadi tegangan rendah, sehingga dapat terbaca oleh instrumen pengukuran dan proteksi (Linquip Team, 2021). Artinya selain berfungsi untuk pengukuran tegangan generator, tegangan sekunder PT juga digunakan sebagai input sinyal tegangan relay tegangan lebih untuk bekerja. Mencari tegangan sekunder yang terukur pada PT dapat menggunakan Persamaan (2).

$$
V_{2}=\frac{V_{T}}{a}
$$

Keterangan :

$\mathrm{V}_{2} \quad=$ Tegangan sisi sekunder PT

$\mathrm{V}_{\mathrm{T}} \quad=$ Tegangan terminal generator

$a \quad=$ Rasio PT yang digunakan

\subsubsection{Pengaturan Tegangan Pada Relay Tegangan Lebih}

Salah satu fungsi relay proteksi adalah untuk mengetahui letak dan jenis gangguan yang terjadi pada sistem tenaga listrik, sehingga dapat mengirimkan sinyal atau indikator peringatan (Tasiam, 2017). Relay harus memiliki unit instantanous dan unit tunda waktu dengan karakteristik inversetime untuk menentukan waktu kerja relay saat mendeteksi gangguan. Tegangan setting unit instantanous umumnya diatur $130 \%$ hingga $150 \%$ dari tegangan terminal generator (tegangan yang terukur pada PT) sedangkan unit inversetime diatur sekitar $110 \%$ dari tegangan terminal (IEEE Guide for AC Generator Protection, 2006). 


\subsubsection{Perhitungan Waktu Kerja Relay}

Setelah didapatkan tegangan setting relay, kemudian diatur waktu tunda atau durasi relay bekerja setelah relay membaca tegangan setting tersebut. Berdasarkan standar IEC (IEC Standard, 2010), cara untuk menentukan waktu kerja relay sesuai dengan parameter tegangan keluaran generator dapat dihitung menggunakan Persamaan (3).

Keterangan :

$$
t=T M S x\left(\frac{k}{\left(\frac{V 2}{V S}\right)^{a}}\right)+c
$$

$\mathrm{t} \quad=$ Waktu operasi (detik)

$V_{2} \quad=$ Tegangan terukur pada PT

$\mathrm{V}_{\mathrm{S}} \quad=$ Pengaturan tegangan pada relay

TMS = Time multipier setting

$\mathrm{k}, \mathrm{a}, \mathrm{c}=$ Konstanta karakteristik IDMT $(\mathrm{k}=1, \mathrm{a}=1, \mathrm{c}=0)$

\subsection{Simulasi Kerja Relay}

Langkah-langkah untuk mensimulasikan setting relay proteksi secara berurutan yaitu membuat SLD (Single Line Diagram) atau skema jalur kelistrikan pada sistem pembangkit, memasukkan data sistem, mengatur skenario gangguan pada sistem pembangkit, menghitung setting relay, memasukkan relay pada SLD, dan terakhir mensimulasikan kerja relay (Saputro, 2016). Simulasi yang dilakukan yaitu dengan skenario pelepasan beban generator, dimana pada saat terjadi pelepasan beban maka akan terjadi lonjakan tegangan keluaran atau terminal pada generator dengan karakteristik seperti yang terlihat pada grafik Gambar 3.

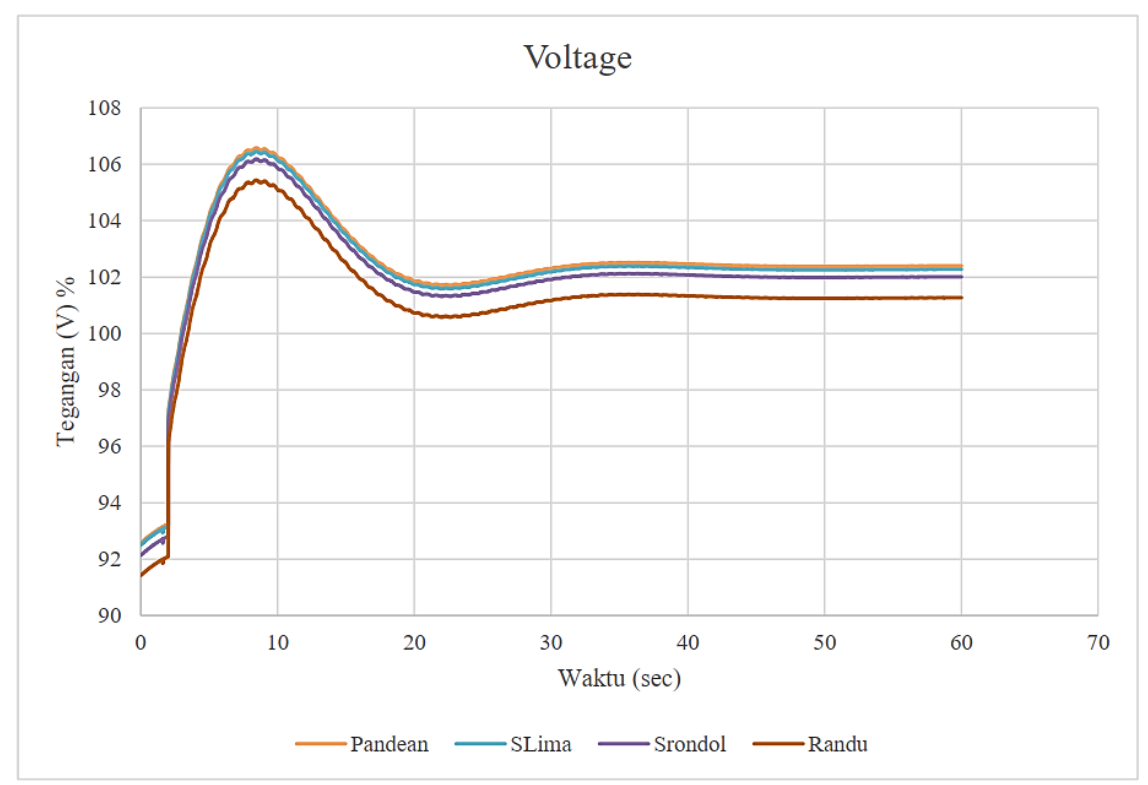

Gambar 3. Grafik Kenaikkan Tegangan Generator Saat Pelepasan Beban (Jozi, 2020)

Berdasarkan Gambar 3, dapat dilihat bahwa tegangan generator akan mengalami kenaikkan pada saat terjadi pelepasan beban, sehingga skenario pelepasan beban dapat dipakai untuk menguji sistem proteksi tegangan lebih pada generator. Untuk penelitian ini, simulasi 
pelepasan beban yang akan digunakan yaitu menggunakan software ETAP dengan durasi simulasi selama 20 detik.

Proses simulasi pelepasan yang akan dilakukan pada software ETAP dapat dilihat pada diagram alir Gambar 4.

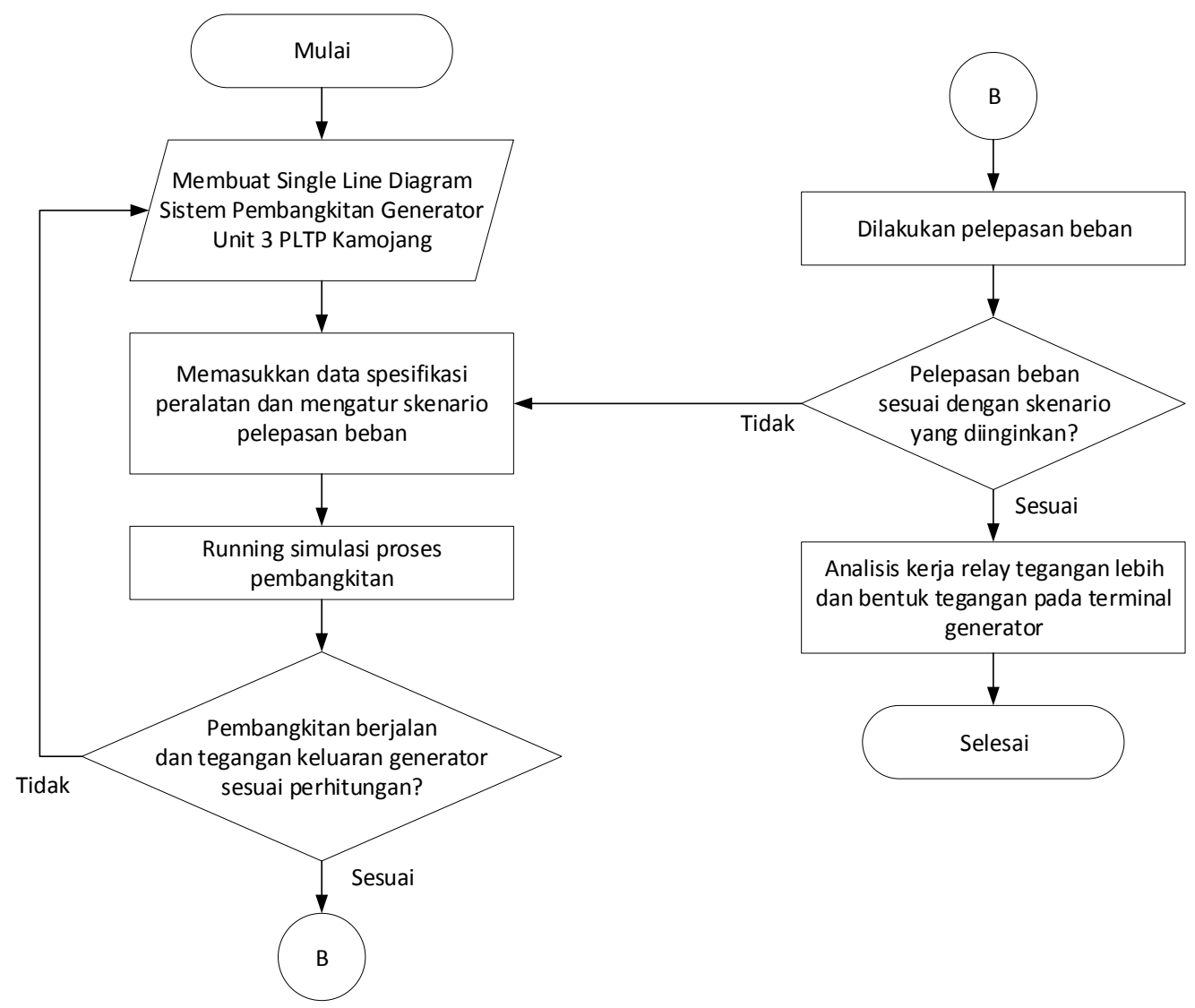

\section{Gambar 4. Diagram Alir Simulasi}

Berdasarkan Gambar 4, proses simulasi dimulai dengan membuat SLD dari sistem pembangkitan generator Unit 3 PLTP Kamojang yang diambil dari data SLD PLTP Kamojang.

Setelah membuat SLD sistem pembangkitan generator Unit 3, kemudian memasukkan data spesifikasi setiap peralatan pembangkit seperti spesifikasi generator, setting relay, trafo daya, bus, motor pompa, dan CB (Circuit Breaker). Selain itu dimasukkan data beban yang disuplai oleh generator seperti spesifikasi peralatan auxilliary dan beban grid yang terhubung dengan jaringan PLN. Selanjutnya yaitu mengatur skenario pelepasan beban menggunakan fitur Transient Stability Analysis yang terdapat pada ETAP, dengan data yang diatur yaitu durasi simulasi, titik CB yang akan dilepas, dan waktu pelepasan CB.

Selanjutnya yaitu melakukan running sistem pembangkitan dengan cara melakukan Load Flow Analysis, setelah simulasi running maka akan terlihat apakah proses pembangkitan berjalan atau tidak, kemudian tegangan yang dihasilkan generator sesuai dengan perhitungan atau tidak, jika tidak maka akan dilakukan pengecekkan kembali apakah terdapat kesalahan pembuatan SLD dan spesifikasi setiap komponen pembangkit atau tidak.

Apabila proses pembangkitan berjalan dan tegangan keluaran generator sesuai dengan perhitungan, selanjutnya dilakukan pelepasan beban dengan melakukan running Transient 
Stability Analysis. Setelah simulasi transient berjalan, dilakukan pengecekkan nominal tegangan pada terminal generator secara berkala dengan menggeser plot waktu durasi simulasi dan dilihat apakah terjadi pelepasan beban atau tidak, kemudian dilihat apakah terjadi gangguan tegangan lebih pada saat terjadi pelepasan beban atau tidak.

Jika terjadi gangguan tegangan lebih kemudian dilihat dan dilakukan analisis apakah sistem proteksi tegangan lebih menggunakan relay tegangan lebih bekerja atau tidak.

\section{HASIL DAN PEMBAHASAN}

\subsection{Perhitungan Tegangan pada Terminal Generator}

Generator Unit 3 PLTP Kamojang yang digunakan untuk skenario gangguan tegangan lebih ini memiliki spesifikasi sebagai berikut:

$\begin{array}{ll}\text { Phase } & : 3 \\ \text { Frekuensi } & : 50 \mathrm{~Hz} \\ \text { Tegangan } & : 11.800 \text { Volt } \\ \text { Kapasitas Daya } & : 55 \mathrm{MW} \\ \text { Faktor Daya } & : 0,8 \text { lagging } \\ \text { Kecepatan } & : 3000 \mathrm{rpm} \\ \text { Jumlah Kutub } & : 2 \text { kutub }\end{array}$

Pada penelitian ini, diambil sampel beban yang didapat dari data beban mingguan yang disuplai oleh generator Unit 3 selama satu bulan, untuk mendapatkan nominal tegangan terminal atau keluaran generator. Berikut ini adalah data pembangkitan generator unit 3 di PT. Indonesia Power PLTP Kamojang pada bulan Agustus 2017.

Tabel 1. Data Pembangkitan Generator Unit 3 PLTP Kamojang Bulan Agustus 2017

\begin{tabular}{|c|c|c|c|c|c|c|c|c|}
\hline $\begin{array}{c}\text { Minggu } \\
\text { ke }\end{array}$ & $\begin{array}{c}\text { Daya Nyata } \\
\text { (MW) }\end{array}$ & $\begin{array}{c}\text { Daya Reaktif } \\
\text { (MVAR) }\end{array}$ & $\begin{array}{c}\text { Tegangan } \\
(\mathbf{k V})\end{array}$ & $\begin{array}{c}\text { Frekuensi } \\
(\mathbf{H z})\end{array}$ & $\begin{array}{c}\text { Cos } \\
\boldsymbol{\varnothing}\end{array}$ & \multicolumn{3}{|c|}{ Arus (kA) } \\
\hline $\mathbf{1}$ & 53,3 & 15,3 & 11,8 & 50 & 0,96 & 2,7 & 2,7 & 2,7 \\
\hline $\mathbf{2}$ & 52,8 & 5,7 & 11,8 & 50 & 0,99 & 2,6 & 2,6 & 2,6 \\
\hline $\mathbf{3}$ & 54,6 & 9 & 11,8 & 50 & 0,98 & 2,7 & 2,7 & 2,7 \\
\hline $\mathbf{4}$ & 55,2 & 8 & 11,8 & 50 & 0,98 & 2,7 & 2,7 & 2,7 \\
\hline
\end{tabular}

Untuk dilakukan perhitungan, diambil sampel data pada minggu ke-1 yaitu 53,3 MW, sehingga didapatkan nilai tegangan terminalnya yaitu:

$$
\begin{aligned}
V_{T} & =\frac{P_{3 \emptyset}}{\sqrt{3} \cdot I \cdot \cos \theta} \\
& =\frac{53,3 \times 10^{3}}{\sqrt{3} \times 2,7 \times 10^{3} \times 0,96} \\
& =11,8 \mathrm{kV}
\end{aligned}
$$

Dari hasil perhitungan didapat tegangan sebesar $11,8 \mathrm{kV}$ dimana nilai ini sesuai dengan kapasitas nominal spesifikasi generator Unit 3. 


\subsection{Perhitungan Tegangan Sekunder PT}

Untuk mendapatkan tegangan sekunder yang terukur pada PT dapat menggunakan Persamaan (2), dengan rasio PT yang dipakai yaitu 118 yang artinya tegangan terminal generator yang sebenarnya merupakan 1:118 dari nilai tegangan sekunder pada PT, sehingga untuk mendapatkan tegangan sekunder PT dapat diketahui dengan perhitungan:

$$
\begin{aligned}
V_{2} & =\frac{V_{T}}{a} \\
& =\frac{11,8 \times 10^{3}}{118} \\
& =100 \mathrm{~V}
\end{aligned}
$$

Tegangan sekunder PT ini merupakan tegangan yang akan terbaca oleh relay tegangan lebih. Relay akan bekerja berdasarkan pengaturan tegangan lebih yang dihitung berdasarkan standar yang dipakai.

\subsection{Pengaturan Tegangan pada Relay Tegangan Lebih}

Sebelum melakukan perhitungan untuk setting relay tegangan lebih, akan dilakukan identifikasi mengenai setting yang telah diterapkan oleh PT. Indonesia Power Kamojang pada relay tegangan lebih yang terpasang pada terminal generator Unit 3. Spesifikasi dan setting relay tegangan lebih yang dipakai adalah sebagai berikut:

$\begin{array}{ll}\text { Nomor Device } & \text { : 59GA } \\ \text { Model Relay } & : \text { TV-2D } \\ \text { Manufaktur } & : \text { MELCO } \\ \text { Rasio PT } & : 11800 / 100 \mathrm{~V} \\ \text { Catu Daya } & : 110 \mathrm{~V} \\ \text { Setting Range } & : 75-135 \mathrm{~V} \\ \text { Setting Dipakai } & : 110 \mathrm{~V} \\ \text { Phasa } & : \text { S - T } \\ \text { Kategori Fungsi } & : \text { Alarm }\end{array}$

Setelah diketahui spesifikasi dan setting relay tegangan lebih yang dipakai, kemudian dilakukan perhitungan pengaturan tegangan kembali untuk diterapkan pada relay yang akan dipakai di simulasi. Berdasarkan standar IEEE Std C37.102 ${ }^{\mathrm{TM}}$-2006: IEEE Guide for AC Generator Protection, relay tegangan lebih dengan jenis inverse time diatur $110 \%$ dari tegangan sekunder PT. Sehingga didapat settingan tegangan pada relay yaitu:

$$
100 \times 110 \%=110 \text { Volt }
$$

Jadi pengaturan tegangan untuk relay tegangan lebih yang dipakai dengan persentase $110 \%$ yaitu sebesar 110 volt, nilai ini sama dengan nilai setting yang terpasang pada terminal generator Unit 3 PLTP Kamojang, artinya setting yang diterapkan mengikuti standar IEEE Std C37.102 ${ }^{\mathrm{TM}}-2006$. Kemudian untuk mengetahui besar tegangan terminal generator yang sebenarnya pada saat mencapai nilai setting yaitu dengan cara mengalikan tegangan setting relay yang terbaca dengan rasio PT yang digunakan yaitu $118 \times 110=13 \mathrm{kV}$. Artinya, relay akan bekerja apabila mendeteksi tegangan pada PT naik hingga mencapai $110 \mathrm{~V}$ atau $13 \mathrm{kV}$ pada tegangan terminal generator yang sebenarnya. 


\subsection{Perhitungan Waktu Kerja Relay Tegangan Lebih}

Untuk mengetahui waktu kerja relay tegangan lebih, dilakukan perhitungan berdasarkan Persamaan (3):

$$
\begin{aligned}
t & =T M S x\left(\frac{k}{\left(\frac{V 2}{V s}\right)^{a}}\right)+c \\
& =1 \times\left(\frac{1}{\left(\frac{100}{110}\right)^{1}}\right)+0 \\
& =1,1 \text { detik }
\end{aligned}
$$

Nilai TMS didapat dari karakteristik relay yang digunakan yaitu 1. Dari hasil perhitungan dapat diketahui bahwa relay akan memberikan perintah menyalakan alarm 1,1 detik setelah relay mendeteksi tegangan lebih.

\subsection{Simulasi Setting Relay}

Langkah pertama untuk melakukan simulasi yaitu membuat sistem diagram satu garis (SLD) generator Unit 3 PLTP Kamojang dan sistem pembangkitannya, yang didapat dari data gambar SLD sistem pembangkitan PLTP Kamojang pada saat observasi lapangan. Gambar 4 menunjukkan SLD sistem pembangkit generator Unit 3.

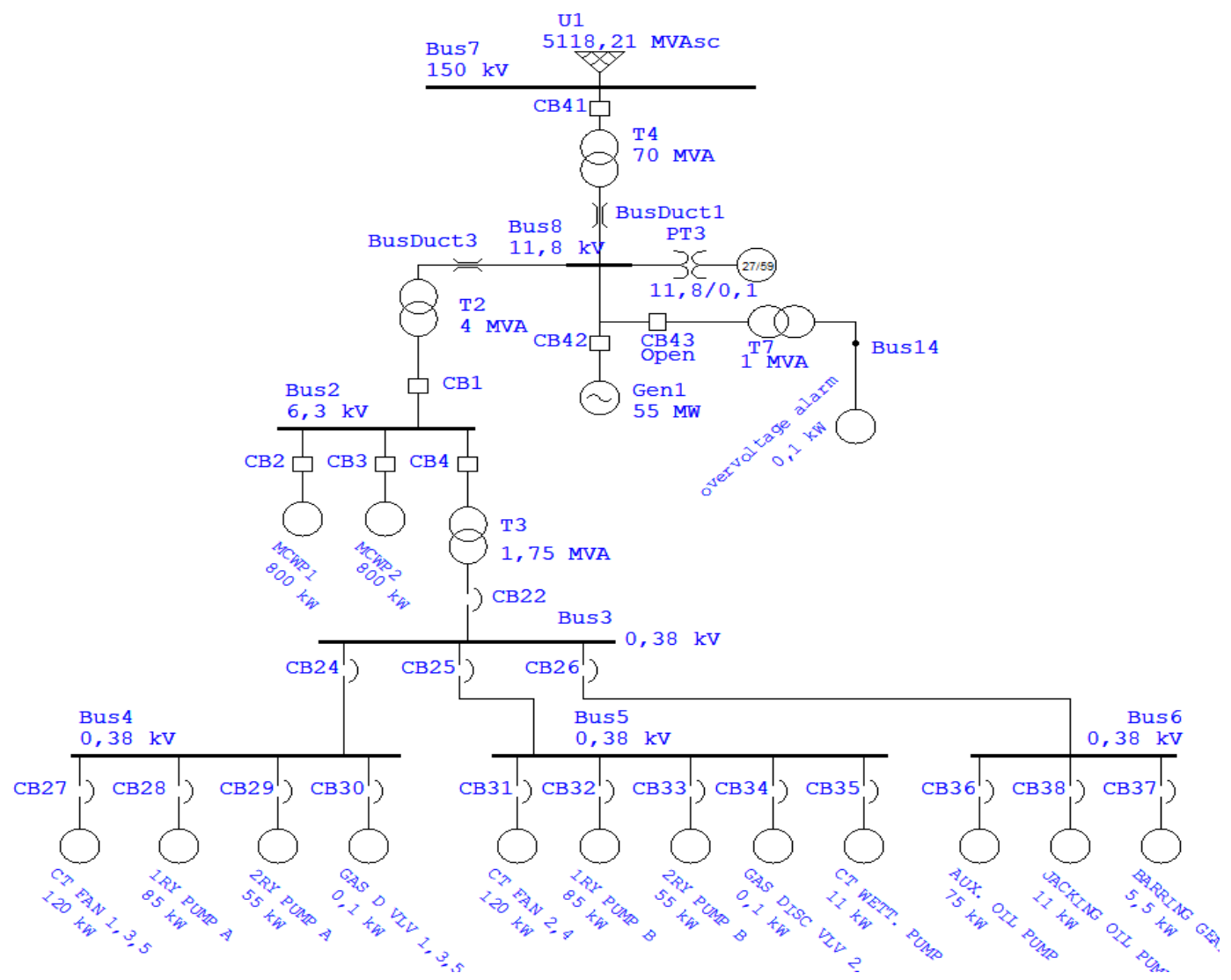

Gambar 4. Single Line Diagram Unit 3 PLTP Kamojang pada ETAP

Berdasarkan SLD pada Gambar 4, relay tegangan lebih (27/59) dipasang pada terminal generator atau Bus8 melalui trafo tegangan PT3, kemudian untuk beban yang disuplainya merupakan peralatan auxiliary dan grid $150 \mathrm{kV}$ sebesar 50,7 MW. Prinsip kerjanya yaitu pada saat relay tegangan lebih membaca tegangan sesuai pengaturan yang diberikan, maka relay 
tersebut akan memberikan sinyal/perintah kepada CB43 (Circuit Breaker) untuk closed sehingga menyalakan motor yang diasumsikan sebagai alarm. Selanjutnya yaitu memasukkan spesifikasi setiap peralatan pada pembangkit, seperti yang dapat dilihat pada Gambar 5.
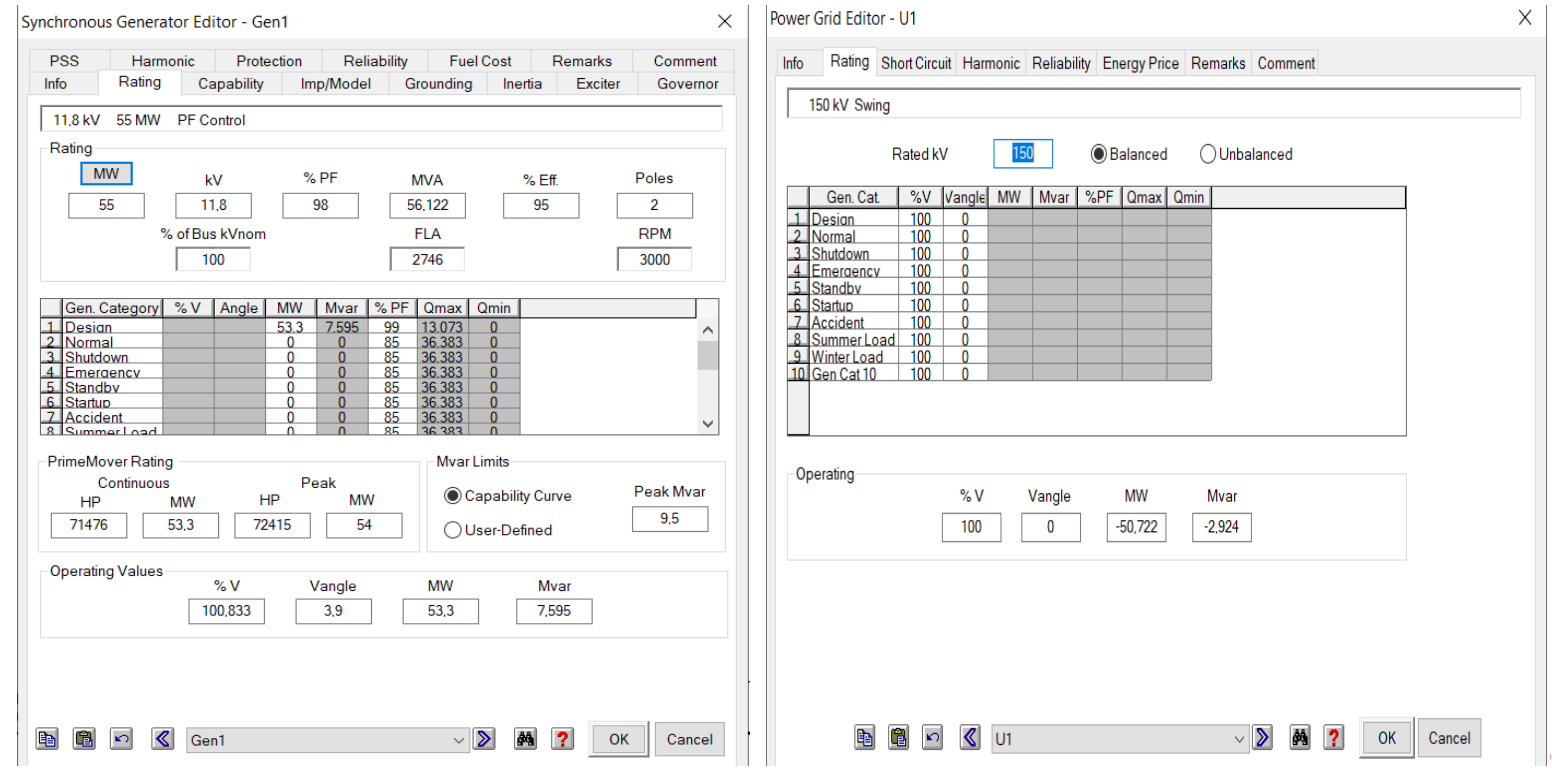

\section{Gambar 5. Spesifikasi Generator Unit 3 dan Grid yang Disuplai}

Kemudian setting relay tegangan lebih yang telah dihitung sebelumnya juga dimasukkan, seperti yang dapat dilihat pada Gambar 6.

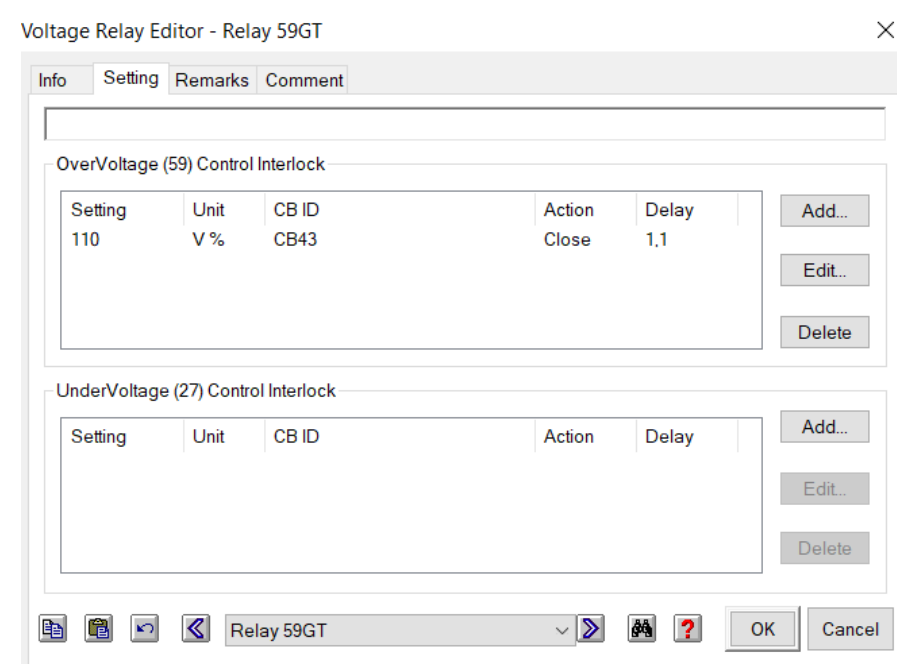

\section{Gambar 6. Setting Relay Tegangan Lebih yang Terpasang pada Teminal Generator}

Berdasarkan Gambar 6, dapat dilihat relay yang dipakai adalah jenis 59GT dimana ini adalah jenis relay tegangan yang terdapat pada ETAP. Kemudian waktu kerja relay yang diatur adalah 1,1 detik kemudian untuk mengatur cara memberi peringatan ketika terjadi gangguan tegangan lebih yaitu dengan menggunakan fitur interlock yang berfungsi untuk mengintegrasikan kerja dua atau lebih komponen dalam sistem pembangkit. Pada simulasi ini, relay tegangan lebih interlock dengan CB43 yaitu CB yang terhubung dengan motor, dimana apabila relay mendeteksi tegangan lebih maka dengan delay yang telah diatur akan 
menjalankan perintah untuk menutup (closed) CB43 sehingga motor akan terhubung dengan sumber tegangan dan menyala sebagai peringatan terjadinya gangguan tegangan lebih.

Setelah spesifikasi dan setting relay dimasukkan, kemudian dilakukan pengaturan study case untuk melakukan skenario pelepasan beban dengan fitur Transient Stability Analysis. Gambar 7 berikut merupakan data dan pengaturan untuk pelepasan beban.

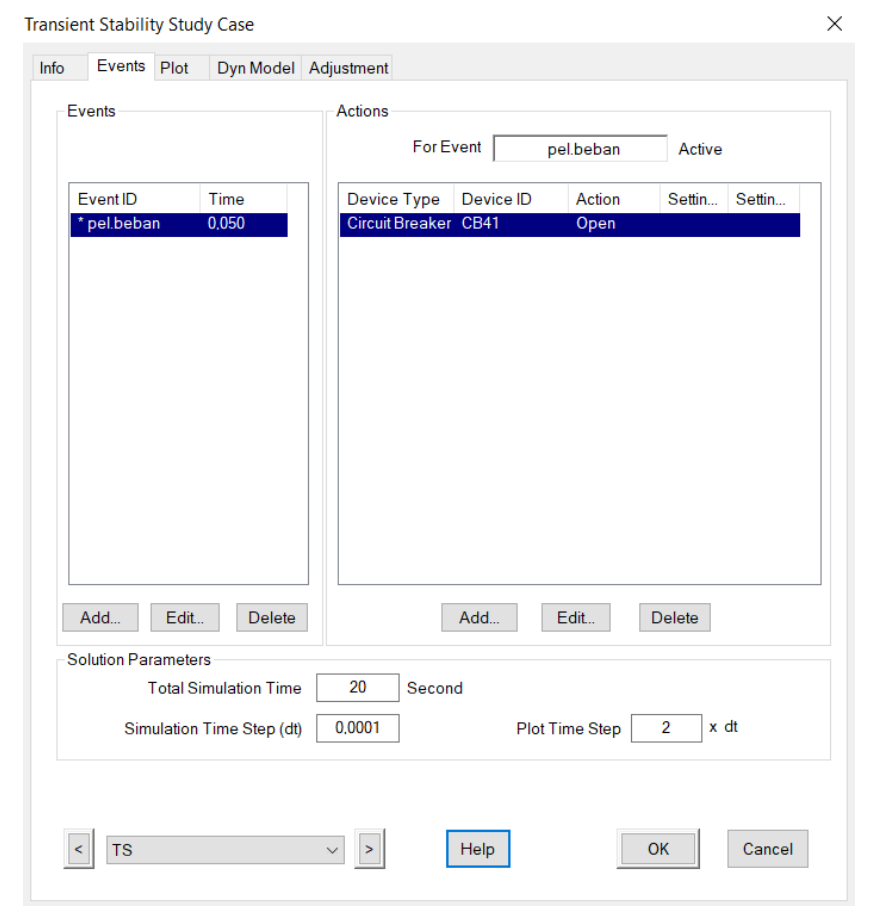

\section{Gambar 7. Pengaturan Study Case Pelepasan Beban}

Gambar 7 menunjukkan informasi mengenai pengaturan dan skenario yang dibuat untuk melakukan pelepasan beban. Simulasi ini dilakukan selama 20 detik, kemudian pada bagian Events ditambahkan skenario yang akan dilakukan dan waktu terjadinya skenario tersebut. Pada bagian events ini diberikan nama skenario pelepasan beban yang dilakukan pada detik ke 0,05 dengan melakukan perintah open pada CB41 yaitu CB yang menghubungkan generator dengan beban grid.

Setelah memasukkan data spesifikasi dan setting setiap komponen yang digunakan kemudian dilakukan simulasi Load Flow Analysis untuk melihat apakah proses pembangkitan berjalan sesuai dengan perhitungan atau tidak. Hasil running Load Flow Analysis dapat dilihat pada Gambar 8. 


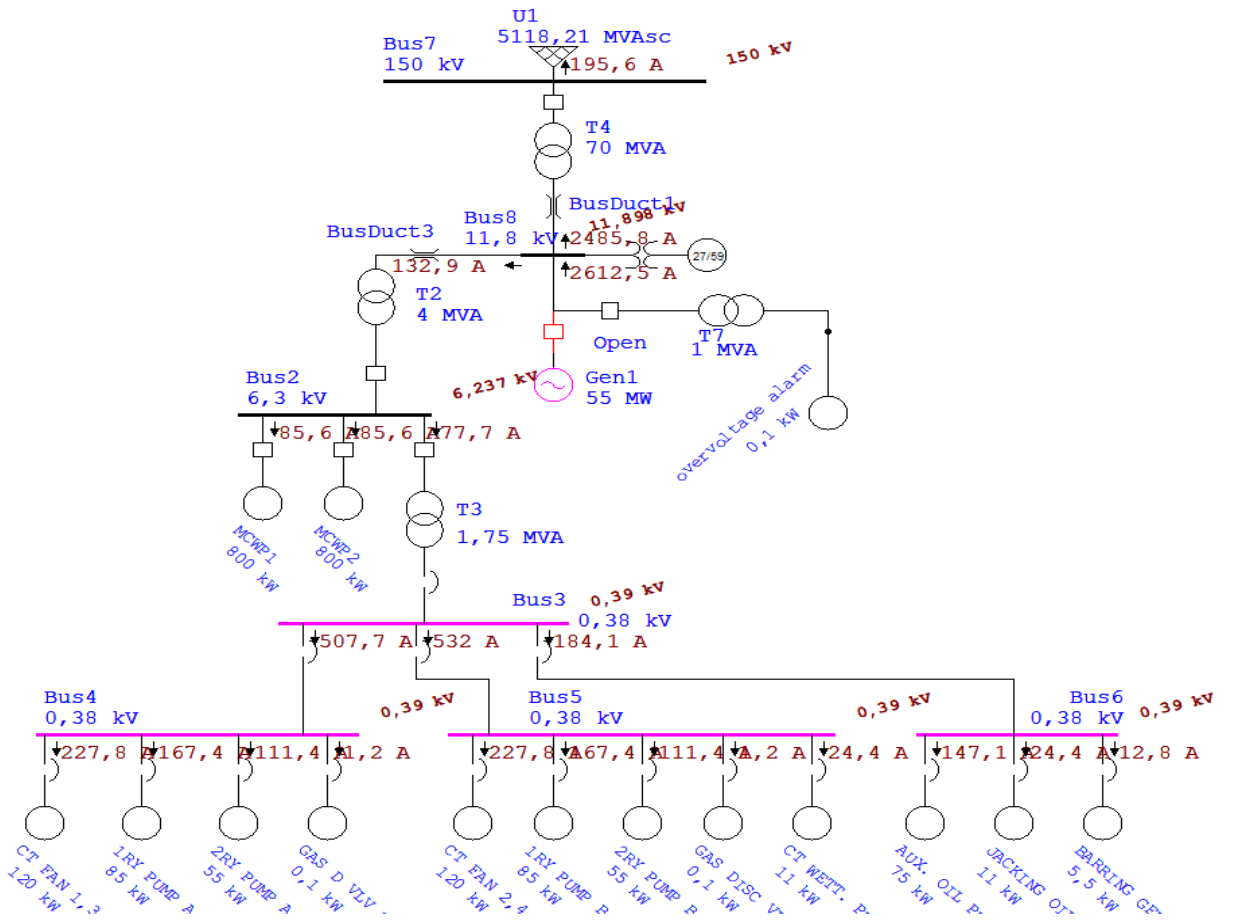

\section{Gambar 8. Generator Unit 3 pada Saat Menyuplai Beban Sebesar 53,3 MW}

Gambar 8 memperlihatkan proses simulasi yang sudah dimulai dengan Load Flow Analysis. Dapat dilihat proses pembangkitan berjalan pada saat sistem pembangkit generator Unit 3 menyuplai beban 53,3 MW atau 96,9\% dari kapasitas daya generator, dimana 95,12\% dari total beban yang sedang disuplai merupakan beban pada grid yang akan dilepas yaitu 50,7 MW sedangkan 4,88\%-nya merupakan beban auxiliary atau kebutuhan sendiri seperti pompa pendingin, motor, dan peralatan instrumentasi. Tegangan terminal generator pada saat menyuplai beban sesuai dengan hasil perhitungan yaitu $11,8 \mathrm{kV}$, sehingga proses pembangkitan berjalan sesuai perhitungan dan dapat dilanjutkan ke tahap berikutnya yaitu pelepasan beban menggunakan Transient Study Analysis. Hasil running simulasi Transient Study Analysis untuk pelepasan beban dapat dilihat pada Gambar 9.

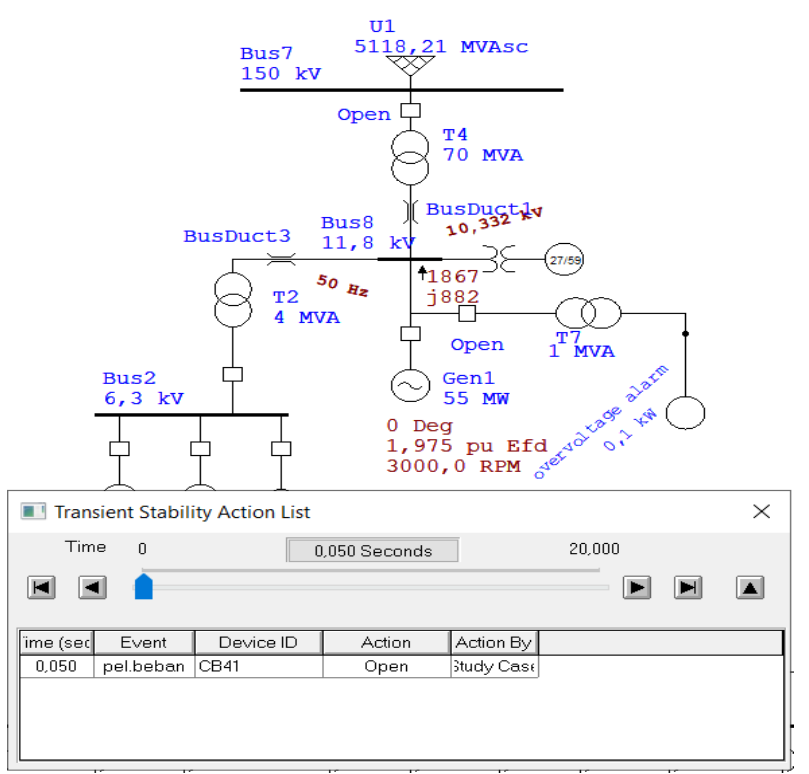

Gambar 9. Kondisi Generator Unit 3 dan Bus Terminal Generator Saat Pelepasan Beban 
Gambar 9 memperlihatkan proses simulasi Transient Study Analysis saat running. Kemudian plot waktunya digeser secara berkala hingga mencapai 0,05 detik seperti yang sudah diatur pada study case. Hasilnya dapat dilihat bahwa terjadi pelepasan beban di CB41 pada Bus7 $150 \mathrm{kV}$ pada detik ke 0,05 sesuai dengan setting yang telah diberikan. Pelepasan beban tersebut menyebabkan penurunan tegangan pada terminal generator menjadi $10,33 \mathrm{kV}$, namun setelah mengalami penurunan kemudian tegangan naik mencapai nilai $13 \mathrm{kV}$ atau $110,17 \%$ dari nominal pada detik ke 1,4 atau 1,35 detik setelah dilakukan pelepasan beban, seperti yang terlihat pada Gambar 10 .

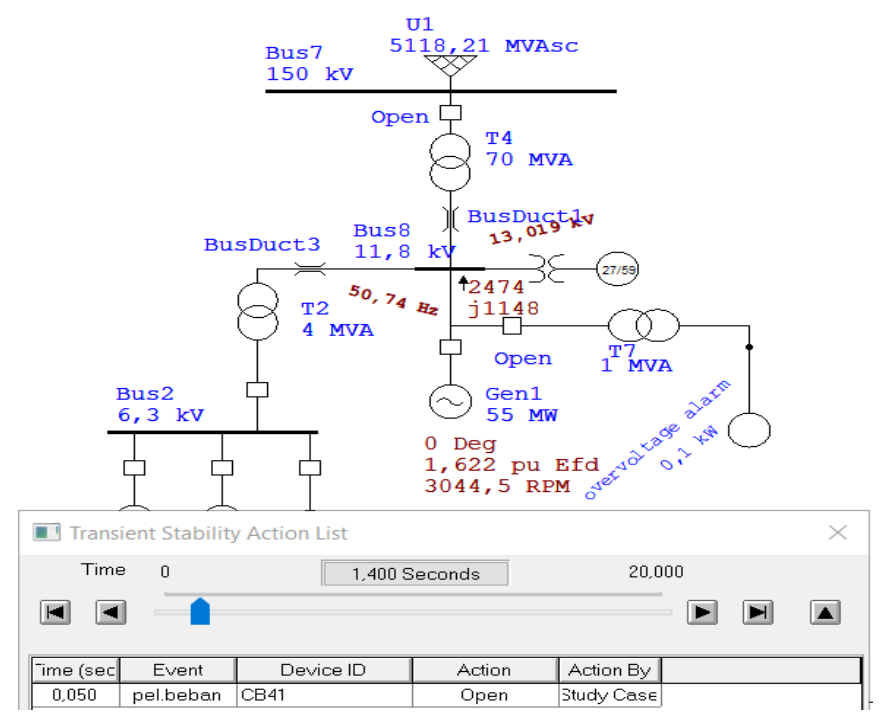

\section{Gambar 10. Kondisi Generator Unit 3 dan Bus Terminal Generator di Detik ke-1,4}

Gambar 10 memperlihatkan terjadinya kenaikkan tegangan mencapai $13 \mathrm{kV}$ pada terminal generator. Berdasarkan perhitungan setting relay sebelumnya, relay akan bekerja pada saat tegangan keluaran generator bernilai $13 \mathrm{kV}$ sehingga pada saat pelepasan beban ini relay akan bekerja untuk memberikan sinyal kepada alarm dengan waktu tunda selama 1,1 detik. Hasil perhitungan sesuai dengan simulasi, dimana relay tegangan lebih bekerja pada detik ke 2,5 atau 1,1 detik setelah terminal generator mengalami kenaikkan tegangan mencapai 13 $\mathrm{kV}$, seperti yang terlihat pada Gambar 11.

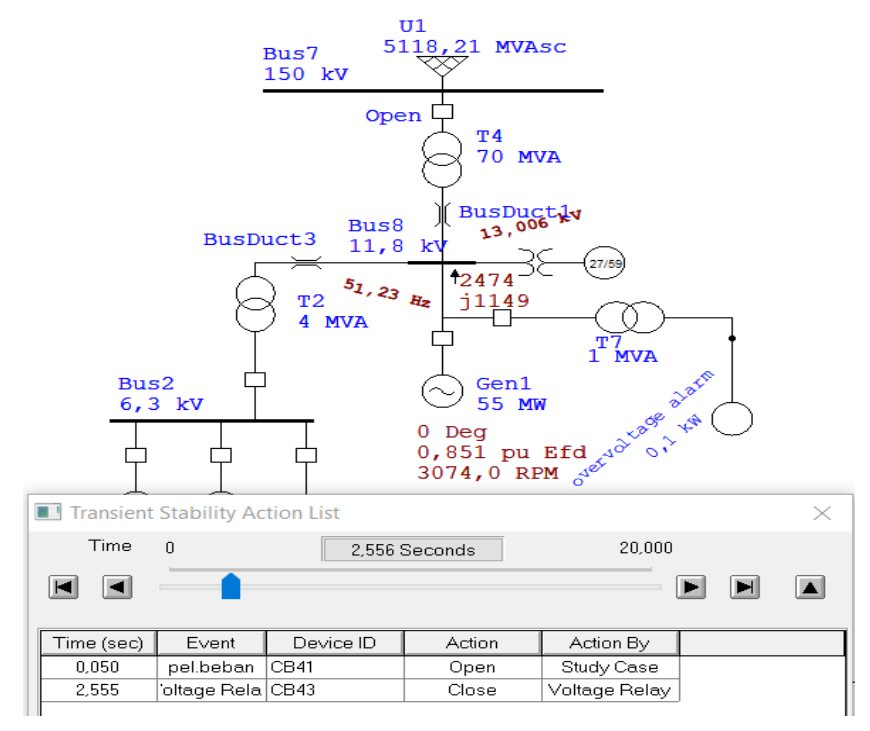

Gambar 11. Kondisi Bus Terminal Generator pada Saat Relay Tegangan Lebih Bekerja 
Berdasarkan Gambar 11 kita dapat mengetahui bahwa pada detik ke 2,5 atau 1,1 detik setelah tegangan terminal generator mencapai nilai $13 \mathrm{kV}$, relay tegangan lebih yang dipasang pada bus8 (terminal generator) melalui trafo PT membaca kenaikkan tegangan ini dan memberikan sinyal ke CB43 agar closed atau terhubung untuk menyalakan motor sebagai alarm. Hal ini menunjukkan bahwa simulasi sudah benar karena relay bekerja sesuai dengan hasil perhitungan setting relay. Grafik perubahan tegangan terminal generator pada saat simulasi Transient Stability Analysis selama 20 detik dan terjadi pelepasan beban dapat dilihat pada Gambar 12.

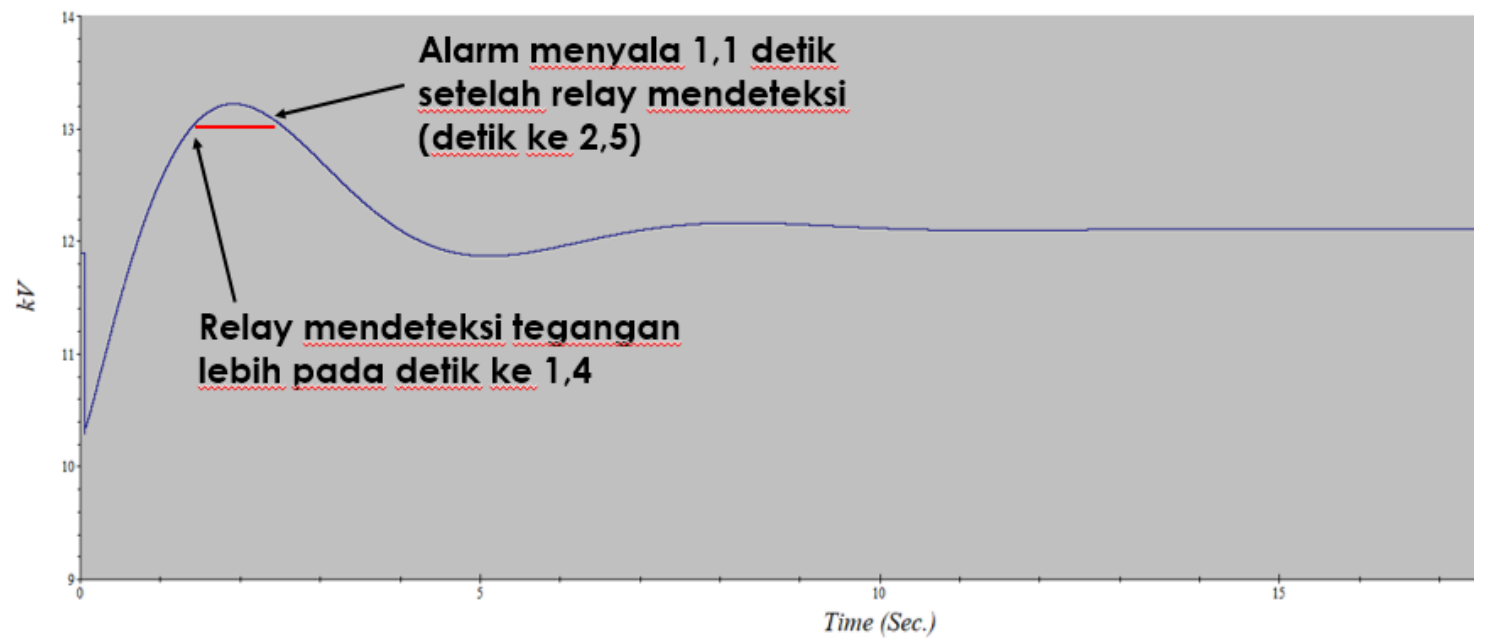

Gambar 12. Grafik Tegangan pada Terminal Generator

Berdasarkan grafik pada Gambar 12 diatas, terlihat bahwa pada saat terjadi pelepasan beban, tegangan terminal yang sedang berjalan pada nilai nominalnya yaitu sebesar $11,8 \mathrm{kV}$ turun sesaat menjadi $10,3 \mathrm{kV}$ yang kemudian naik selama 1,65 detik hingga mencapai puncaknya sebesar $13,2 \mathrm{kV}$ atau $119,8 \%$ dari nilai nominal selama 0,013 detik.

Kemudian tegangan berangsur turun selama kurang lebih 5 detik sampai tegangan mulai turun hingga stabil pada nilai $12 \mathrm{kV}$ dimana besar tegangan ini masih dibawah batas maksimal tegangan lebih yaitu sebesar $13 \mathrm{kV}$. Hal ini terjadi karena sistem eksitasi generator yang berfungsi untuk menghasilkan tegangan induksi terhubung dengan AVR (Automatic Voltage Regulator) yang berfungsi untuk mengatur arus medan yang diinjeksikan dalam pembangkitan tegangan. Sehingga pada saat terjadi kenaikkan tegangan akibat pelepasan beban mendadak, AVR menyesuaikan tegangan yang dibangkitkan agar tegangan lebih yang terjadi tidak berlangsung lama yang dapat menyebabkan kerusakan isolasi belitan generator. Setelah dilakukan simulasi pelepasan beban sebesar 50,3 MW atau 95,12\% dari total beban sebesar 53,3 MW, terjadi kenaikkan tegangan hingga 119,8\% dari tegangan nominal yang kemudian terdeteksi oleh relay tegangan lebih yang disetting bekerja pada saat tegangan naik mencapai $110 \%$ dari tegangan nominal. Berdasarkan simulasi, relay bekerja sesuai setting yang diberikan yaitu pada saat tegangan nominal $11,8 \mathrm{kV}$ naik $110 \%$ menjadi $13 \mathrm{kV}$ dengan delay selama 1,1 detik dengan memberikan instruksi closed pada CB alarm, sehingga alarm menyala pada saat 2,5 detik setelah terjadi gangguan tegangan lebih.

\section{KESIMPULAN}

Berdasarkan hasil analisis, dapat disimpulkan bahwa tegangan maksimum untuk proteksi tegangan lebih pada generator Unit 3 PLTP Kamojang yaitu sebesar $13 \mathrm{kV}$ pada terminal generator. Dengan sistem proteksi yang digunakan yaitu penyalaan alarm pada saat mendeteksi gangguan tegangan lebih menggunakan relay tegangan lebih, dengan cara relay 
mendeteksi tegangan pada PT dan memiliki waktu tunda kerja selama 1,1 detik. Hasil perhitungan dan simulasi menunjukkan bahwa setting yang dipakai sudah sesuai dengan salah satu standar yang mengatur proteksi generator yaitu standar IEEE Std C37.102 ${ }^{\mathrm{TM}}$ 2006.

\section{UCAPAN TERIMA KASIH}

Penulis ucapkan terimakasih kepada semua pihak yang telah membantu penulis dalam melaksanakan penelitian ini, khususnya kepada PT. Indonesia Power UPJP Kamojang yang telah memberikan kesempatan kepada penulis untuk melaksanakan penelitian.

\section{DAFTAR RUJUKAN}

ElProCus Technologies Pvt Ltd. (2020, March 5). What is a Potential Transformer: Construction, Types \& its Applications. Retrieved from Elprocus: https://www.elprocus.com/what-is-a-potential-transformer-construction-types-itsapplications/

Grabovickic, R. (2012). Protection of Transformer-ended Feeders Using Multifunction Relays. PES T\&D 2012 , (pp. 1-10).

Grid, A. (2011). Network Protection \& Automation Guide: Protective Relays Measurement \& Control. Stafford: Alstom.

Hidayat, S. (2018). Perancangan Proteksi dan Monitoring Generator Sinkron Tiga Fase Berbasis Arduino Mega 2560. Dielektrika, 6(1), 141-153.

Hussen, M. S. (2019). Overview of Generetor Protection on Power System. International Journal of Engineering Applied Sciences and Technology, 3(11), 12-18.

IEC Standard. (2010). Measuring Relays and Protection Equipment-Part 127: Functional Requirements for Over/under Voltage Protection. IEC 60255-127.

IEEE Guide for AC Generator Protection. (2006). IEEE Std C37.102-2006 (Revison of IEEE Std C37.102-1995), (pp. 1-177).

Jozi, R. F. (2020). Analisis Mekanisme Pelepasan Beban terhadap Pengaruh Kestabilan Frekuensi dan Tegangan Akibat Putusnya Generator pada Gardu Induk Tambak Lorok. Prosiding Konferensi IImiah Mahasiswa Unissula (KIMU) Klaster Engineering, (pp. 70-79).

Linquip Team. (2021, May 5). What is Potential Transformer? Retrieved from Linquip: https://www.linquip.com/blog/what-is-potential-transformer/

Saputro, T. D. (2016). Evaluasi Setting Relay Proteksi Generator Pada Plan PT. Petrochina International Jabung Ltd. Betara Complex Development Project Menggunakan Simulasi Etap 12.6.0. Transient: Jurnal IImiah Teknik Elektro, 4(4), 1100-1109. 
Shintawaty, L. (2014). Sistem Proteksi pada Generator di PLTG Musi 2 Palembang. Jurnal Desiminasi Teknologi, 6(1), 1-12.

Smith, T. (2011). Fundamentals of Modern Protective Relaying (Part 1). GE Digital Energy.

Sudjoko, R. (2018). Rancang Bangun Sistem Proteksi Generator Sinkron 3 Phasa Terhadap Arus Beban Lebih dan Drop Tegangan Berbasis Mikrokontroler Arduino. Jurnal Penelitian, 3(2), 25-36.

Tasiam, F. J. (2017). Proteksi Sistem Tenaga Listrik. Yogyakarta: Teknosain.

Torres, F. (2008). Application of Overvoltage Protection to the Peruvian Power System. Western Protective Relay Conference, (pp. 506-512).

Widarsono, K. (2019). Relay Protection of Over Voltage, Under Voltage and Unbalance Voltage Magnitude Based on Visual Basic Using Arduino Mega. Seminar MASTER PPNS, 4(1), 39-48. 